\title{
DATA ON THE OCCURRENCE OF CALCIFICATION IN THE EYE TISSUES* $\dagger$
}

\author{
BY
}

\author{
MAGDa RadNót
}

BUDAPEST

ONE of the most widely known degenerations of the cornea occurs in the form of zonular opacity, which can be observed in the region of the palpebral aperture in the form of a band narrowing towards the centre from the limbus, leaving here a narrow strip of the cornea free. The anatomical basis of this clinical picture is a calcified degeneration of the layers under the epithelium of the cornea. The text-books distinguish two or three forms of zonular opacity. One is pathologically quite a different deformation, occurs as an occupational injury, principally to hat-makers, and is caused by the deposit of rabbit hairs in the cornea. The other two forms are the so-called primary and secondary ribbon-type degeneration, the difference between them being that the primary occurs in eyes otherwise healthy, the secondary in damaged eyes, usually those blinded by uveitis. Merz-Wigandt has warned that this distinction is not justifiable, as it is possible that the primary also occurs in previously injured eyes but that it cannot be demonstrated clinically.

As we have intimated, the essential change is a lime deposit. This, according to Leber, develops the clinical form of zonular opacity, because the greatest degree of evaporation is in the region where the eye opens and the calcium precipitates here from the greater calcium-containing liquid coming into the cornea. This explanation is not universally accepted, but, as Hippel remarked, no one knows a better one. Imre's observation is very interesting, to the effect that in one case of transplantation of the cornea because of zonular opacity, a change similar to zonular opacity showed itself in the transplanted disc too.

In the following we deal with cases of the so-called ribbon-type degeneration, seeking what changes we find in the other tissues of the eye,-first of all whether we find calcareous deposits elsewhere too.

Calcification also occurs in the cornea secondarily in leucoma and, very seldom, in the form of primary calcareous deposit. In Axenfeld's well-known primary case and in one case of Imre's the cause of the calcareous deposit could not be cleared up. These changes do not come within the limits of the present investigations, no more do those cases when lime is deposited in the cornea in connection

\footnotetext{
*Publication of the Ophthalmological Clinic No. II Budapest (Director, Professor Tibor Nónay). 
with lime injury (Lisch), nor the lime deposit occurring in osteomalacia (Spanlang).

At a meeting of the Hungarian Ophthalmological Society on October 5, 1941, we presented 6 cases, 4 of which were zonular opacity, the other 2 consisting of lime in the cornea in the form of irregular deposits. In all 6 cases we found lime deposits in other tissues of the eye-ball also. Since then we have, with special attention to this viewpoint, investigated the eye-balls in the corneas of which we saw calcareous degeneration. In the following, on the

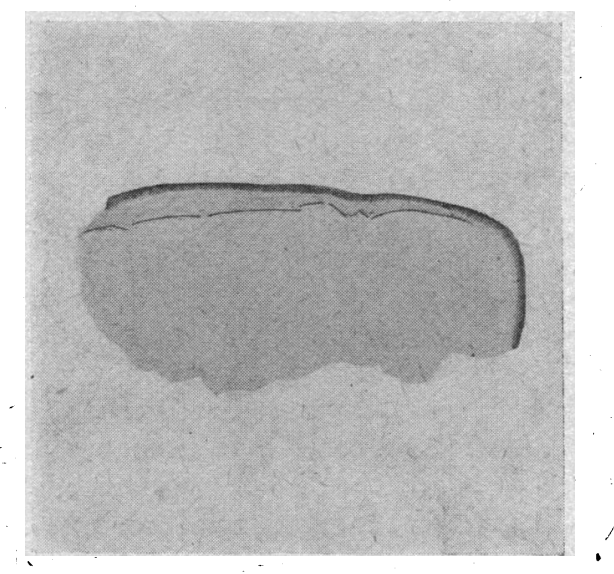

FIG. 1.

Calcareous deposits in Bowman's membrane and beneath it.

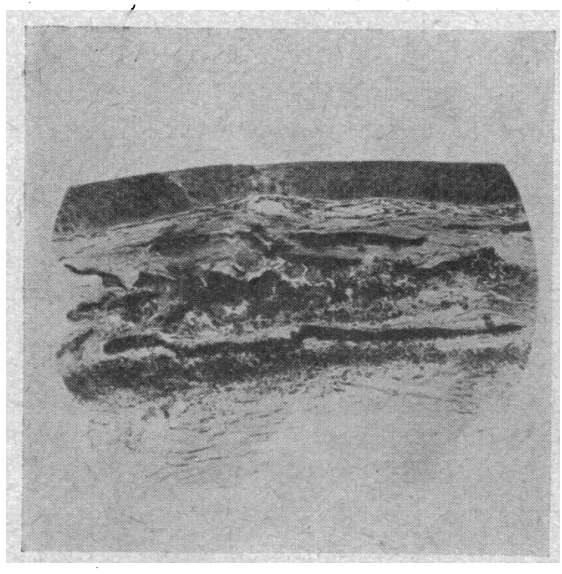

FIG. 2.

Bowman's membrane absent.

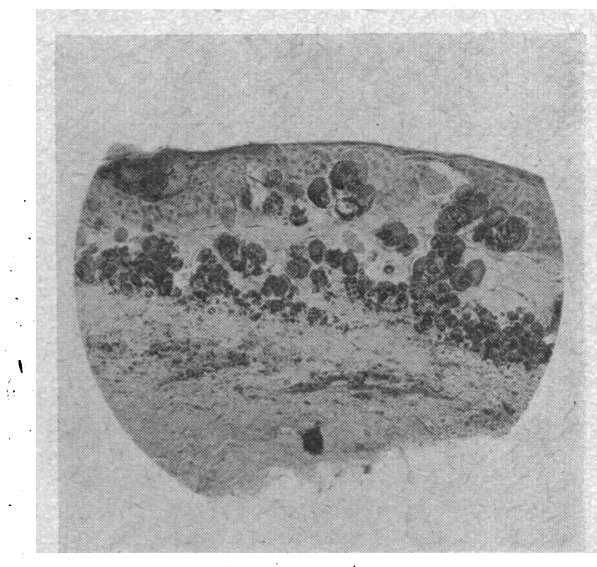

FIG. 3.

Calcareous scar tissue under the epithelium. 
basis of 12 cases, we describe the occurrence of lime in the eye tissues. In ten of them lime was deposited in the cornea as zonular opacity, in the other two in an irregular form.

Walsh mentions similar degeneration of the conjunctiva in a case of zonular opacity arising after iridocyclitis, and under a figure of Hippel's we read that "Bandförmige Hornhauttrübung . . . Auge mit ungewöhnlich starker Verkalkung in der Retina.".

In a case of zonular opacity we found calcareous deposit in the region of Bowman's membrane and in the form of discs in layers under it (Fig. 1). In most cases hyaline granules could also be found

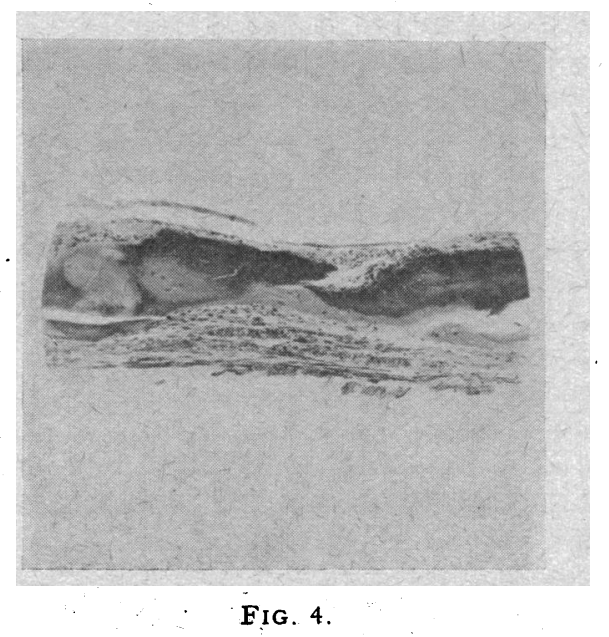

Bone lamellae in the choroid.

beside the calcareous lamellae. In the more advanced cases the calcification is very extensive. Bowman's membrane is lacking, and scar-tissue develops under the epithelium (Figs. 2 and 3). Limecan most frequently be found in the choroid also in these cases, that is, in bone lamellae. Besides the changes in the cornea to be seen in Figs. 2 and 3, we found bone lamellae in the choroid (Fig. 4). Much more extensive bone formation is to be seen in the case shown in Fig. 5, where, in addition, a calcareous degeneration is also to be observed in the-subluxated lens. Somewhat more rare is the deposit of lime in the degenerate retina, or in chorio-retinitis scars (Fig. 6).

If the lime deposit is extensive the changes will be perceptible with X-rays. In Fig. 7 can be seen a bone cup in place of the choroid and the calcified lens; the same bone cup dissected is shown in Fig. 8. In Fig. 9 is a case of greater calcification of the lens, with a smaller amount of lime observable in the choroid. The $\mathrm{X}$-ray photographs were taken by Dr. Luzsa. 
MAGDí RADNót

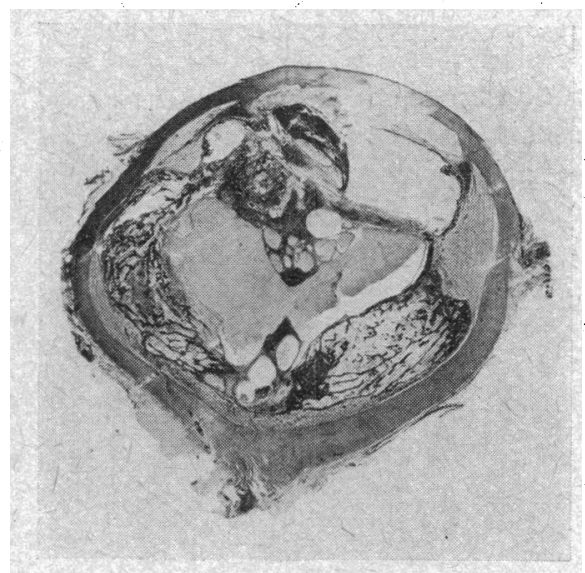

Fig. 5.

Half eye showing extersive bone formation and calcareous degeneration.

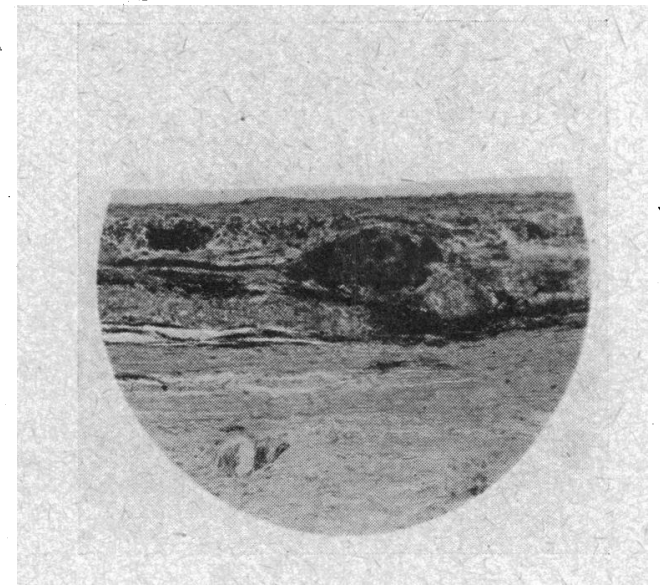

Fig. 6.

Lime deposit in degenerate retina.

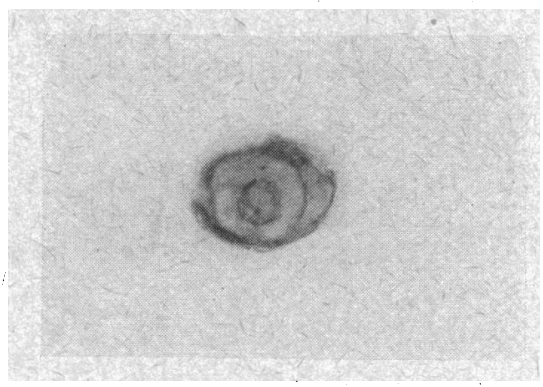




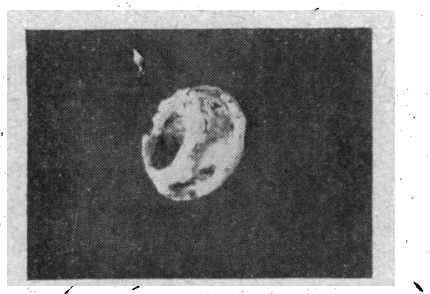

Fig. 8:

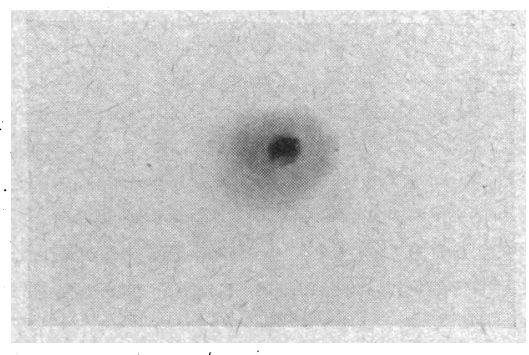

Fig. 9.

Bone cup dissectèd out of eye.

Lens more calcified than in Fig. 7, choroid less calcified. X-ray photograph.

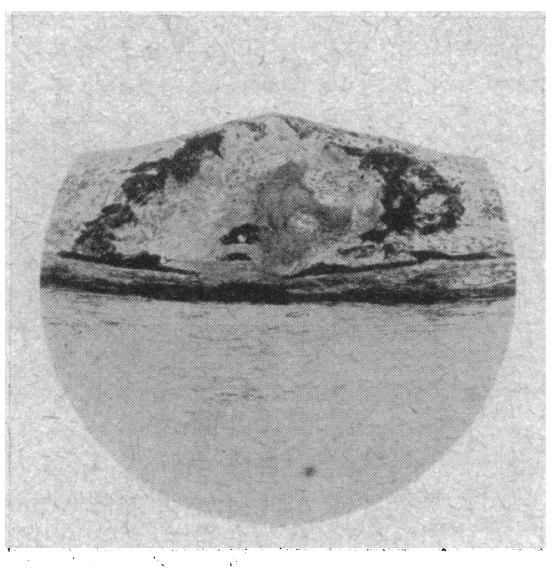

Fig. 10.

Bone lamellae in chorio-rétinal scar.

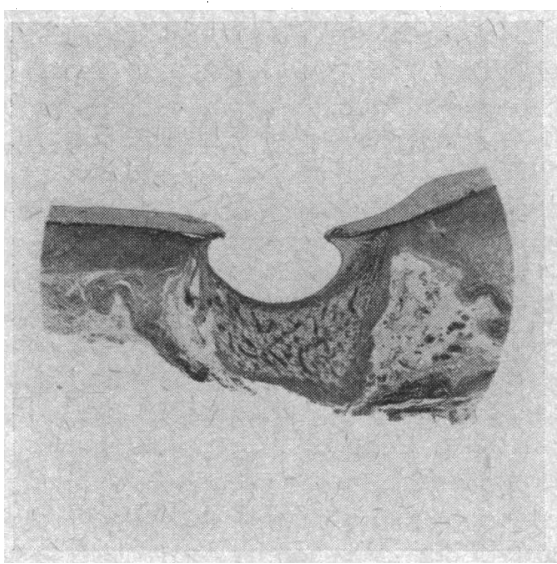

FIG. 11 .

Secondary glaucoma, accompanying chronic uveitis. 
Cataracta calcarea, according to Szily's observations, generally occurs in connection with uveitis and accompanies lime deposit in the choroid.

In exceptional cases the bone formation can extend into the tissues of the cornea, as in ' $Z$ wiauer's case.

In chorio-retinal scars not only simple lime deposits but also the formation of bone lamellae is possible (Fig. 10). Zonular opacity is to be observed in most cases in atrophied eyes, and in Fig. 11

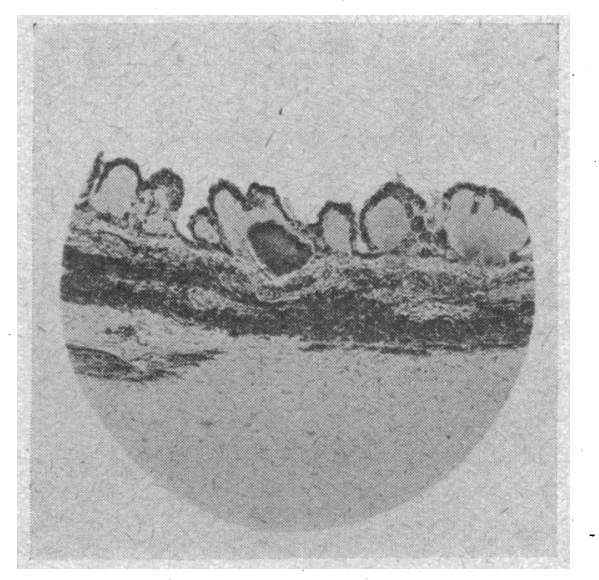

FIG. 12.

Calcareous deposits in lamina vitrea warts.

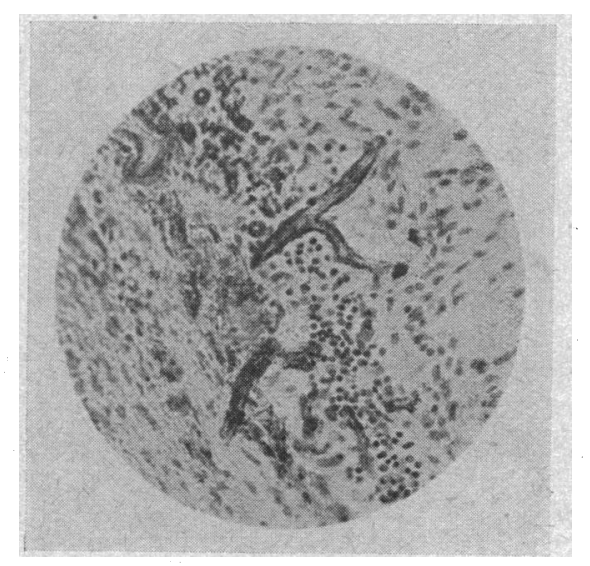

Fig. 13. 


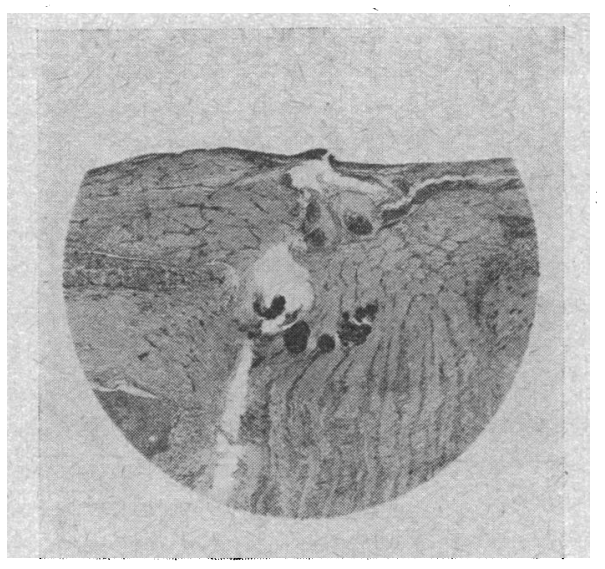

FIG. 14.

Calcareous lamellae in optic nerve.

there can be seen in a case of ours the secondary glaucoma accompanying chronic uveitis which led to enucleation (Fig. 11).

In atrophied eyes lamina vitrea warts are very often to be seen, but only very rarely is a lime deposit found in them, as in Fig. 12. In the same case we saw calcareous deposition in the layer of the retina which was wholly detached and gathered into wrinkles in the anterior part of the vitreous body (Fig. 13). In the wall of the bigger obliterated vessels, or in the hyaline centres which are to be found in their place, the lime deposit is principally to be seen in the detached retina.

It does not strictly belong to our subject but because of its rarity we present Fig. 14, where we find lime lamellae in the optic nerve in an eye blinded by a malignant exophthalmos. The corpora amylacea occurring in the covering of the optic nerve usually contain more or less lime.

On the basis of our investigations, therefore, we see that when lime is deposited in the cornea in zonular opacity or in eyes injured in some other way, a lime deposit is also to be found in the other tissues of the eye-ball.

\section{REFERENCES}

ABELsdorfF.-Sehnerv. in Henke-Lubarsch Hd. d. spec. Path, etc. Bd., Vol. XI, p. $1,1928$.

AXENFELD-Klin. Monatsbl.f. Augenheilk., Vol. LVIII, p. 58, 1917.

HipPel. - Hornhaut, in Henke-Lubarsch Hb. d. spez. Path. etc. Bd., Vol. XI, p. 1, 1928.

IMRE.- Klinische und histologische Erfahrungen mit der Hornhautübertragung. Bücherei d. Augenarztes H. 14. Enke. Verlag., 1942.

JAF:NSCH.-Die Altersveränderungen und Entartungen des Auges. LubarschOstertag Ergebnisse etc. Bd. 26 Ergänzungsbańd., 1933. 
LEBER.-Ber. Ophthal. Ges. Heidelberg. S., Vol. LIII, 1897.

LisCH.-Graefe's Arch., Vol. CXLII, p. 503, 1941.

MERZ-WIGANDT.-Klin. Monatsbl.f. Augenheilk.. Vol. LXXVIII, p. 205. 1927.

Spanlang.-Zeitschr.f. Augenheilk., Vol. LXII, p. 21, 1927.

SzILY.-Linse, in Henke-Lubarsch Hb. d. spez. Path. etc, Bd., Vol. XI, p. 3, 1939.

Walsh.-Amer. Jl. Ophthal., Vol. XVII.p. 238, 1934.

ZWIAUER.-Graefe's Arch., Vol. CXLII, p. 68, 1941.

\title{
TREATMENT OF PERFORATED CORNEAL ULCER, BY AUTOPLASTIC SCLERAL TRANSPLANTATION* +
}

\author{
BY \\ SVEN LARSSON \\ LUND
}

THE method generally used in trying to close a persistant corneal defect is either that of covering it with conjunctiva which has been detached in some way, or that of corneal grafting. In cases where the defect lies outside the optic zone, and optical considerations do not arise, a conjunctivoplasty would seem to be the current method, and is in fact successful in most cases. If, however, transparency is aimed at, transplantation of cornea has lately been used with ever increasing frequency.

In the literature at my disposal I have found no account of attempts to close a persistent corneal defect or fistula by transplantation of sclera taken from the patient's own eye. Such an attempt will be described here.

The patient, a seven year old girl, M.E. $977 / 45$, had previously been healthy. In July, 1945, a left-sided exophthalmus occurred, and as the X-ray examination showed a decalcification of the left wing of the sphenoid the doctor in charge of the case suspected a tumour with intracranial extension. The patient was, therefore, sent to the neuro-surgical clinic of the Serafimer Hospital in Stockholm. - A copy of the patient's case history has been placed at our disposal.

The following data were recorded on admittance on September 14, 1945 :

$$
\text { Vision R.E. 5/5, L.E. 5/10. }
$$

The right eye showed no symptoms of abnormality.

The left eye protruded considerably. Hertel's exophthalmometer showed $13 \mathrm{~mm}$. for the right eye and $19 \mathrm{~mm}$. for the left eye, i.e., an exophthalmos of $6 \mathrm{~mm}$.

* Received for publication, July 23, 1947.

† From the Ophthalmic Clinic of the University of Lund, Sweden. Chief : Professor Sven Larsson. 